\title{
Ecosystem service modelling
}

\author{
Maike Hamann, $, 2,3^{*}$ Justin A. Johnson, ${ }^{3,4^{*}}$ Tomas Chaigneau, ${ }^{5}$ \\ Rebecca Chaplin-Kramer, ${ }^{3,6}$ Lisa Mandle ${ }^{6}$ and Jesse T. Rieb \\ ${ }^{1}$ CENTRE FOR SUSTAINABILITY TRANSITIONS, STELLENBOSCH UNIVERSITY, STELLENBOSCH, SOUTH AFRICA \\ 2 HUMPHREY SCHOOL OF PUBLIC AFFAIRS, UNIVERSITY OF MINNESOTA, MINNEAPOLIS, MINNESOTA, USA \\ ${ }^{3}$ NATURAL CAPITAL PROJECT, INSTITUTE ON THE ENVIRONMENT, UNIVERSITY OF MINNESOTA, SAINT PAUL, MINNESOTA, USA \\ ${ }^{4}$ DEPARTMENT OF APPLIED ECONOMICS, UNIVERSITY OF MINNESOTA, SAINT PAUL, MINNESOTA, USA \\ ${ }^{5}$ ENVIRONMENT AND SUSTAINABILITY INSTITUTE, UNIVERSITY OF EXETER, PENRYN, UK \\ ${ }^{6}$ NATURAL CAPITAL PROJECT, WOODS INSTITUTE FOR THE ENVIRONMENT, STANFORD UNIVERSITY, STANFORD, \\ CALIFORNIA, USA \\ ${ }^{7}$ DEPARTMENT OF NATURAL RESOURCE SCIENCES, MCGILL UNIVERSITY, SAINTE-ANNE-DE-BELLEVUE, CANADA \\ *THESE AUTHORS CO-LED THIS CHAPTER
}

\section{Key methods discussed in this chapter}

Decision-support modelling packages: Integrated valuation of ecosystem services and trade-offs (InVEST), artificial intelligence for ecosystem services (ARIES), Co\$ting Nature/ WaterWorld

Related technical models and frameworks: Integrated assessment models, general equilibrium models, Lund-Potsdam-Jena dynamic global vegetation model, Life Cycle Assessment models

\section{Connections to other chapters}

Ecosystem service modelling connects to a number of other methods, since ecosystem service assessments usually form part of a larger decision-support initiative. Systems scoping (Chapter 5) may lay the foundation for an ecosystem service assessment, while ecosystem service models may be developed through participatory modelling and planning (Chapter 13), and feed directly into scenario development (Chapter 11) or a livelihood and vulnerability analysis (Chapter 32). The results of ecosystem service modelling are usually mapped spatially (Chapter 24) and often support decision analysis based on optimisation (Chapter 29).

\section{Introduction}

The study of social-ecological systems (SES) is mainly concerned with understanding the interactions between people and nature. Ecosystem services represent an important subset of these interactions. They are the benefits from nature that support and fulfil human life 


\begin{tabular}{|c|c|}
\hline \multicolumn{2}{|c|}{ SUMMARY TABLE: ECOSYSTEM SERVICE MODELLING } \\
\hline DISCIPLINARY BACKGROUND & KNOWLEDGE TYPE \\
\hline $\begin{array}{l}\text { The methods in this chapter are derived } \\
\text { from or have most commonly been used in: } \\
\text { Ecology, Resource Economics, } \\
\text { Computational Geography, Systems } \\
\text { Dynamics, Computer Science, } \\
\text { Information Science }\end{array}$ & $\begin{array}{l}\text { The methods in this chapter are primarily } \\
\text { used to generate the following types of } \\
\text { knowledge: } \\
\text { - Explanatory } \\
\text { - Prescriptive }\end{array}$ \\
\hline RESEARCH APPROACH & PURPOSE OF METHOD \\
\hline $\begin{array}{l}\text { The methods in this chapter originate } \\
\text { from or most commonly adopt the } \\
\text { following research approaches: } \\
\text { - Analytical/objective } \\
\text { - Collaborative/process }\end{array}$ & $\begin{array}{l}\text { The most common purposes of using the } \\
\text { methods in this chapter are: } \\
\text { - System understanding } \\
\text { - Stakeholder engagement and } \\
\text { co-production } \\
\text { - Policy/decision support }\end{array}$ \\
\hline TEMPORAL DIMENSION & SYSTEMIC FEATURES AND PROCESSES \\
\hline $\begin{array}{l}\text { The methods in this chapter are most } \\
\text { commonly applied to the following } \\
\text { temporal dimensions: } \\
\text { - Present (typically within the last } \\
5-10 \text { years) } \\
\text { - Recent past (post-1700s) } \\
\text { - Future }\end{array}$ & \multirow[t]{3}{*}{$\begin{array}{l}\text { While most methods can do many } \\
\text { things, the methods in this chapter are } \\
\text { particularly good (i.e. go-to methods) for } \\
\text { addressing the following: } \\
\text { - SES components and linkages } \\
\text { - Social-ecological dependence } \\
\text { and impact } \\
\text { - Evaluating policy options }\end{array}$} \\
\hline SPATIAL DIMENSION & \\
\hline $\begin{array}{l}\text { The methods in this chapter are primarily } \\
\text { either or both: } \\
\text { - Explicitly spatial } \\
\text { The methods in this chapter are most } \\
\text { commonly applied at the following } \\
\text { spatial scales: } \\
\text { - Local } \\
\text { - Regional (provincial/state } \\
\text { to continental) } \\
\text { - Global } \\
\text { Multiple places/sites around the world }\end{array}$ & \\
\hline
\end{tabular}


(Millennium Ecosystem Assessment 2005; Díaz et al. 2015). Coastal habitats such as mangroves, for example, act as a buffer for people and infrastructure along coastlines against the impact of storms. Fields, forests and oceans provide food in the form of crops, game and fish. Natural landscapes around the world are important parts of people's cultural and spiritual identities. Functioning, healthy ecosystems are necessary for the production of ecosystem services, but often some sort of human input or action is also required to enhance the provision of these services and their contribution to well-being, such as forest management or cropland irrigation. Ecosystem services are therefore co-produced by people and nature (Reyers et al. 2013; Palomo et al. 2016).

The concept of ecosystem services has its roots in economics and ecology. One of the first studies to collate information on the economic value of a range of 'nature's services' was published in the late 1970s (Westman 1977), starting a trend of valuing services provided by ecosystems (i.e. natural capital) in a way that made them comparable to human-made goods and services (i.e. manufactured and financial capital). In ecology, the first mention of the term 'ecosystem services' occurred in a 1981 book on species extinctions and their consequences (Ehrlich and Ehrlich 1981). By the end of the 20th century, ecosystem services were formally defined as the 'conditions and processes through which natural ecosystems, and the species that make them up, sustain and fulfil human life' (Daily 1997). Since then, the concept of ecosystem services has moved beyond economics and ecology to become a widely used interdisciplinary approach within sustainability research (Abson et al. 2014).

A variety of methods can be used to quantify ecosystem services, depending on the type of ecosystem service, the spatial and temporal scale, and the scientific question or management decision being considered. Sometimes ecosystem service provision can be measured directly, either through field measurements (methods for generating data, Chapters 6-8) or through remote sensing of variables that are highly correlated with ecosystem service provision (Chapter 24). For instance, all the wheat produced on a field can be weighed, all the fish caught in a lake can be counted, and visits to parks can be tallied. However, direct measurement is usually only an option for a limited area over a limited time and tends to favour services that provide a physical product or have a market value. Often, ecosystem services have not been quantified for a location of interest, or they cannot be measured directly (such as the contribution of natural vegetation to maintaining water quality or regulating floods). Furthermore, decision-makers often need to understand changes in ecosystem service provision under different management scenarios or future conditions. In these cases, ecosystem services need to be modelled or estimated.

One option for modelling ecosystem services is the 'value transfer' or 'benefit transfer' approach, where the per-unit-area provision of ecosystem services from one area is transposed onto another area using a proxy variable such as land cover (see e.g. De Groot et al. 2012). Although this method is simple to use, it assumes similar social and ecological drivers of ecosystem service provision in both locations. Results from this type of approach should therefore be interpreted with caution (Eigenbrod et al. 2010).

Another approach is to construct process-based ecosystem service models, based on knowledge about ecosystem processes and functions that produce benefits for humans (socalled 'ecological production functions'). Process-based ecosystem service models typically translate geospatial inputs (such as land cover, vegetation and soil types, climate and topography) into estimates of an ecosystem service over space and/or time. This translation process occurs within small, standardised area units, such as pixels or parcels. Sometimes, the results for one unit influence the calculations for the next unit, creating a quantification of 
ecosystem service 'flow' between pixels or parcels. Vegetation that retains soil in one pixel will change the amount of sediment flowing into downhill pixels, for example.

While decision-making often involves spatial planning, non-spatial process-based simulation models can also be used to explore the implications of different management decisions for ecosystem service provision, or to explore future scenarios. The outcomes of these models are not necessarily quantitative predictions but rather a qualitative understanding of how different components of an SES interact and connect to one another to provide ecosystem services. Moreno et al. (2014), for example, used a participatory modelling approach to explore the factors affecting ecosystem service provision in protected areas, and found that it helped decision-makers learn about complex systems and identify opportunities for improving ecosystem service management.

\section{SES problems and questions}

Ecosystem service models help to reveal nature's benefits, especially when these benefits would otherwise be 'invisible' in decision-making (Daily 1997; Guerry et al. 2015). Usually, a variety of different ecosystem services are modelled to map and quantify the provision of multiple ecosystem services in a landscape. Ideally, this helps decision-makers to understand the impact of a decision (such as a development plan or land-management strategy) on multiple ecosystem services, and avoids unexpected outcomes where efforts to enhance the provision of one service inadvertently reduce the provision of another (Arkema et al. 2015). Decision-support packages such as InVEST, ARIES and Co\$ting Nature have been designed to facilitate the modelling of multiple ecosystem services, and may assist in processes such as decision analysis based on optimisation (Chapter 29).

Another key application of ecosystem service models is the identification of important areas for conservation or restoration, based on an area's high level of ecosystem service provision (or potential provision) (Naidoo et al. 2008; Mandle et al. 2017; Nel et al. 2017). This approach can also identify which parts of a landscape supply ecosystem services that play a crucial role in supporting local livelihoods (Malmborg et al. 2018) and thus inform a livelihood and vulnerability analysis (Chapter 32). Ecosystem service modelling, and ecosystem service assessments more broadly, provide insights into the diverse ways that ecosystem services contribute to human well-being. These contributions to well-being may, in turn, influence environmental behaviour and the stewardship of natural resources, thereby affecting future ecosystem service provision in a complex set of social-ecological feedbacks (Masterson et al. 2019).

At a global scale, ecosystem service models are increasingly incorporated into other modelling frameworks, such as integrated assessment models and general equilibrium models, to investigate the impact of changes in land use, climate or commodity prices on ecosystems and the services they provide (e.g. Johnson et al. 2020).

Finally, ecosystem services are inherently linked to issues of equity and inclusivity. The provision of ecosystem service benefits depends not only on ecosystems and the functions they perform but also on their location relative to people who might benefit, and people's access to the services (Keeler et al. 2019a, b). Innovative approaches to ecosystem service assessments track how and where environmental changes affect specific beneficiaries, including impacts on the health or livelihoods of poor and marginalised communities (Arkema et al. 2013; Mandle et al. 2015; Chaigneau et al. 2018). These assessments can be used to compare the equity implications of different development options (Mandle et al. 2016). 


\section{Brief description of key methods}

A diverse range of tools and models have been developed to assess ecosystem services (Bagstad et al. 2013; Neugarten et al. 2018). In Table 31.1, we briefly describe a selection of key decision-support modelling packages with a documented, software-based user interface that allows non-experts to run process-based, spatially explicit ecosystem service models. In addition, we describe several technical models and frameworks that are not strictly ecosystem service models, but are often used to generate ecosystem service-specific results in practice.

Table 31.1 Summary of key methods used in ecosystem service modelling

$\begin{array}{lll}\text { Method Description } & \text { References }\end{array}$

\section{DECISION-SUPPORT MODELLING PACKAGES}

Integrated valuation Integrated valuation of ecosystem services and tradeof ecosystem services and trade-offs offs (InVEST) is a suite of over 20 ecosystem service production function models. Typical inputs include land-use and land-cover (LULC) maps, climate data, topographic data and soil data. From these inputs, InVEST applies functions from peer-reviewed literature (e.g. the revised universal soil loss equation) to the input data and calculates ecosystem service provision. Each model is calculated separately, but most analyses then combine results for multiple models. InVEST is open source and developed in the programming language Python.

Artificial intelligence Artificial intelligence for ecosystem services for ecosystem services

(ARIES) is an artificially intelligent modelling platform that chooses which models to run in response to a user query, based on available spatial data and several decision rules.

Methodologically, ARIES focuses on specifying how or where individuals benefit from the flows of ecosystem services from sources to sinks. ARIES is open source, but running the model relies on non-open-source tools (e.g. k.LAB).

\begin{tabular}{lll}
\hline Co\$ting Nature/ & $\begin{array}{l}\text { Co\$ting Nature and WaterWorld are web-based } \\
\text { tools used to estimate terrestrial and freshwater }\end{array}$ & Key introductory text \\
ecosystem services. The models are built on default & Mulligan 2012 \\
& base data, such as soil type or precipitation, which & Applications to SES \\
& allow ecosystem service calculations at detailed & Mulligan et al. 2013 \\
& spatial scales of 1 km or 1 ha resolution. Co\$ting & \\
& Nature includes 13 services, such as hazard & \\
& mitigation, nature-based tourism and timber & \\
& supply. The code is not open source and requires & \\
payment for full functionality. & \\
\hline
\end{tabular}

Key introductory text Kareiva et al. 2011

Applications to SES Mandle et al. 2017; Chaplin-Kramer et al. 2019

Key introductory text Villa et al. 2014

Applications to SES Martínez-López et al. 2019 


\begin{tabular}{|c|c|c|}
\hline Method & Description & References \\
\hline \multicolumn{3}{|c|}{ TECHNICAL MODELS AND FRAMEWORKS } \\
\hline $\begin{array}{l}\text { Integrated } \\
\text { assessment models }\end{array}$ & $\begin{array}{l}\text { Integrated assessment models (IAMs) consider } \\
\text { how changes in climate or the biosphere affect } \\
\text { human activities, and vice versa. Key inputs } \\
\text { include population growth, consumption patterns } \\
\text { and climate change. IAMs are coarse in spatial } \\
\text { resolution (grid cells of } 30-110 \mathrm{~km} \text { ) but detailed in } \\
\text { sectoral information (e.g. crop production figures) } \\
\text { and have many explicit links between humans and } \\
\text { the environment (e.g. through water scarcity or } \\
\text { nutrient cycling). }\end{array}$ & $\begin{array}{l}\text { Key introductory text } \\
\text { Stanton, Ackerman, } \\
\text { and Kartha } 2009 \\
\text { Applications to SES } \\
\text { Van Vuuren et al. } \\
2015\end{array}$ \\
\hline $\begin{array}{l}\text { Economic models } \\
\text { that include } \\
\text { ecosystem services }\end{array}$ & $\begin{array}{l}\text { Several important economic models have been } \\
\text { extended to report ecosystem service outcomes. } \\
\text { These include general equilibrium models that } \\
\text { allow a change in the system to affect other system } \\
\text { components. Typically, these models track how } \\
\text { economic changes affect land-use patterns. These in } \\
\text { turn are translated into impacts on ecosystem services } \\
\text { such as carbon storage and nutrient retention. In } \\
\text { addition, a large body of literature has developed that } \\
\text { models interactions between climate change and the } \\
\text { economy, predicting greenhouse gas emissions as a } \\
\text { function of economic activity while also tracking how } \\
\text { the change in climate causes economic damage. }\end{array}$ & $\begin{array}{l}\text { Key introductory texts } \\
\text { Hertel 1997; } \\
\text { Nordhaus } 2017 \\
\text { Applications to SES } \\
\text { Arndt et al. 2011; } \\
\text { Meyfroidt et al. } 2013\end{array}$ \\
\hline $\begin{array}{l}\text { Lund-Potsdam-Jena } \\
\text { dynamic global } \\
\text { vegetation model }\end{array}$ & $\begin{array}{l}\text { The Lund-Potsdam-Jena (LPJ) dynamic global } \\
\text { vegetation model, along with other similar global } \\
\text { vegetation models, provides detailed information } \\
\text { on plant growth, mortality, soil interactions and } \\
\text { other biophysical components of the model. Core } \\
\text { parts of the LPJ, along with extensions of the model, } \\
\text { report ecosystem service-specific results, such as soil } \\
\text { carbon, water run-off or other factors. There is less } \\
\text { interaction between people and the ecosystem in this } \\
\text { type of model, with the exception of highly detailed } \\
\text { agricultural models. }\end{array}$ & $\begin{array}{l}\text { Key introductory text } \\
\text { Sitch et al. } 2003 \\
\text { Applications to SES } \\
\text { Metzger et al. } 2008\end{array}$ \\
\hline $\begin{array}{l}\text { Life Cycle } \\
\text { Assessment models }\end{array}$ & $\begin{array}{l}\text { Life Cycle Assessment (LCA) models attempt to } \\
\text { quantify the full environmental impact of a product } \\
\text { through the many stages of its life, including the } \\
\text { collection of input resources, assembly, usage } \\
\text { and disposal. Many research institutes and private } \\
\text { consultants have developed highly detailed databases } \\
\text { of the impacts that different products have on the } \\
\text { environment, although relatively few have focused } \\
\text { on ecosystem service-specific impacts. One notable } \\
\text { exception by Chaplin-Kramer et al. (2017) assesses how } \\
\text { land-use and ecosystem service changes prompted by } \\
\text { expanded production can also be included in life-cycle } \\
\text { calculations (see also Chapter 30: Flow and impact } \\
\text { analysis). }\end{array}$ & $\begin{array}{l}\text { Key introductory text } \\
\text { Curran } 1996 \\
\text { Applications to SES } \\
\text { Chaplin-Kramer et } \\
\text { al. } 2017\end{array}$ \\
\hline
\end{tabular}




\section{Limitations}

Ecosystem service models are constrained by data quality. The general computing adage of 'garbage in, garbage out' also holds true for ecosystem service modelling. Beyond data quality, the quantity of data may be a limiting factor. The amount of data to be processed depends on the scale at which an ecosystem service model is applied: as extent increases or resolution becomes finer, computation time increases and it becomes more challenging to find suitable data (see also Chapter 24). In addition, many ecosystem service models rely on information or input assumptions that are not constant across a large extent, thus requiring different inputs for different subregions. Because these factors all increase modelling time and effort, it is important for researchers to identify and work at the optimal scale to answer their specific research questions.

Ecosystem service models can be used to express the value of nature in a diversity of ways, including mental health benefits (Bratman et al. 2015), self-reported importance (Martín-López et al. 2012) or the number of people affected by changes in ecosystem service provision (Olander et al. 2018; Keeler et al. 2019a). In addition, ecosystem service models are often used to quantify benefits in economic or monetary terms. It is important to note that economic value is only a small part of the value of nature and that ecosystem service models can provide a more complete and holistic set of values. However, even when ecosystem services are not given a monetary value, the ecosystem service concept still implies that the value of nature lies in its utility to people. Although the hope is that focusing on people's well-being will help promote nature's value in typical, economically driven decision-making, this 'commodification' of nature goes against the philosophical and spiritual values of many communities, cultures and worldviews (Gomez-Baggethun and Ruiz-Perez 2011; Díaz et al. 2018).

A related key limitation of current ecosystem service models is their relatively poor performance in capturing non-market and cultural values (Chan et al. 2016; Small, Munday, and Durance 2017), with the possible exception of nature-based recreation and tourism (e.g. Wood et al. 2013). Another challenge in capturing non-economic benefits is illustrated by the difficulties (most notably the lack of data availability) faced by modellers to 'disaggregate' the impact of ecosystem services for different groups of people, based on their access to and need for the service (Daw et al. 2011). For details on how many of these limitations are currently being addressed, refer to Section 'New directions' of this chapter.

\section{Resource implications}

Ecosystem service models can require substantial investments in learning to use the modelling software, and in pre-processing data into the correct formats. In addition, model outputs often need further processing and visualisation, which may require proficiency in geographic information system (GIS) software or geoprocessing code. Licences for widely used GIS programs can be very expensive, and high-resolution input data (e.g. satellite imagery) may be costly to acquire.

When involving stakeholders, ecosystem service modelling faces the same time and resource constraints, and must follow the same strict ethical research guidelines as any other participatory modelling process (Chapter 13). Since many ecosystem service models, including the ones outlined in this chapter, rely on Western scientific knowledge and technical expertise, they can appear obscure to stakeholders who rely on other kinds of knowledge systems. This lack of transparency may hinder community buy-in and reduce 
the effectiveness of ecosystem service models in assisting decision-making processes. This is why a thoughtful and respectful approach to using these models is needed, especially in participatory settings.

\section{New directions}

As the popularity of ecosystem services as a tool for addressing social-ecological challenges grows, ecosystem service models are continually changing and developing to better provide the types of information that practitioners require. For instance, improvements in remotesensing technology are enabling the direct observation of more ecosystem services across wide areas and at fine spatial and temporal resolution (Ramirez-Reyes et al. 2019). Yet a number of research frontiers for advancing ecosystem service models remain (Rieb et al. 2017).

The first frontier addresses the shortcoming that current ecosystem service tools typically model multiple ecosystem services using separate models, as a 'snapshot' at a single point in time, and at the scale of a pixel or patch. Models that better represent interactions between multiple ecosystem services and their spatial and temporal dynamics would help decision-makers to predict the full implications of management actions for multiple ecosystem services across a landscape and into the future. Advances in remote-sensing technology and data availability have an important role to play in enhancing dynamic ecosystem service modelling, as well as moving beyond categorical land-cover inputs to more continuous and nuanced (i.e. realistic) input data.

The second frontier concerns the need for ecosystem service models to move beyond merely quantifying the biophysical supply of services to tracking changes in human well-being for different groups of beneficiaries. This includes adopting more meaningful valuation metrics that capture non-use and relational values of nature. An ecosystem service modelling approach that is explicit about beneficiaries, their needs and how changes in ecosystem services either enhance or diminish their well-being is crucial to understanding the role that ecosystem services can play in poverty alleviation and achieving the UN Sustainable Development Goals. Here, conventional models could be supplemented with more exploratory approaches, such as toy models and the use of scenario planning techniques (Chapter 11), to identify trade-offs between groups of people and how they benefit from ecosystem services, both now and in future scenarios (Daw et al. 2015).

The third frontier involves better understanding and modelling the implications of using different types of non-natural capital (e.g. technology, infrastructure and institutions) to produce or distribute ecosystem services. A study of shellfish fisheries in Spain and Portugal, for example, observed multiple ways of co-producing this ecosystem service using different amounts of equipment, active management and human labour, and found that the type of co-production affected the quantity of shellfish produced, as well as trade-offs with other ecosystem services (Outeiro et al. 2017). Key to this research area is understanding the difference that nature makes, relative to and accounting for the other kinds of capital. This frontier also involves understanding the burdens that are placed on ecosystems in one location by trade and decision-making in other, often far-away, parts of the world (Pascual et al. 2017; Schröter et al. 2018). It is especially important to consider global-scale flows of ecosystem services as countries work to develop ecosystem service accounting systems and metrics such as 'green GDP' (Li and Fang 2014).

Other frontiers for ecosystem service modelling lie at the intersection of different model types and the exploration of previously unexplored landscapes. Combining computable general equilibrium models like GTAP with ecosystem service models like InVEST, for example, will help to improve our understanding of cross-scale linkages between regional 


\section{Case study 31.1: Balancing conservation and agricultural expansion in the Volta watershed}

Ecosystem service modelling can help decision-makers to understand potential trade-offs between development and conservation. Johnson et al. (2019) assessed how agricultural expansion may affect ecosystem service provision in the Volta watershed in Burkina Faso and Ghana. The watershed is critical to human livelihoods and well-being for a variety of reasons. Among other things, it supports the Akosombo Dam, which is a vital source of hydroelectric power. Other local livelihood strategies depend on the Volta River and surrounding ecosystems for brick-making and low-capital, low-intensity irrigated agriculture (Figure 31.1A and B). The basin also includes a particularly wide range of ecosystem types due to a strong precipitation gradient, from very dry, Sahara-like conditions in the north to extremely wet and lush ecosystems in the south.

A transnational agency, the Volta Basin Authority (VBA), is responsible for managing water withdrawals and other aspects of dam management, many of which have the potential to cause transboundary disputes. Recently, environmental degradation in the watershed has had detrimental impacts on ecosystem service provision. An increase in soil erosion, for example, has led to increasing sedimentation of reservoirs (in both the Akosombo Dam and smaller, run-of-river dams in the north). In response, the VBA committed to a strategic action programme aimed at preventing further environmental degradation and protecting ecosystem services (World Bank 2018). However, food security is extremely important to policymakers in this region, and thus any conservation plan needed to also consider impacts on food production.

Johnson et al. (2019) considered three different conservation strategies and assessed which lands should be protected in order to meet the VBA's dual goals of protecting ecosystem service provision and food security. InVEST models for sediment retention, phosphorus and nitrogen retention, water yield and carbon storage were run for the basin under the different strategies. The results showed that targeted conservation actions could attain much improved ecosystem service provision over the business-as-usual approach, while still meeting food-security goals through agricultural expansion. The study was limited by regional data availability and had to rely on global datasets for many components. It was also challenging to express the aggregate of multiple ecosystem services in a clear and appropriate way. In the end, an equally weighted overall ecosystem service score was created for the region based on the model results, and used to identify priority areas for conservation (Figure 31.1C).

This case study illustrates that ecosystem service modelling can highlight both conflicts and synergies between development and conservation goals in a spatially explicit manner, and provide decision-makers with a range of options to consider.

or global market or policy changes and local-level ecosystem service provision (Johnson et al. 2020). In addition, the increasing availability of fine-scale land-cover data down to the resolution of individual trees has opened up avenues to explore urban landscapes and the ecosystem service provision by 'green infrastructure' (such as street trees, parks, 

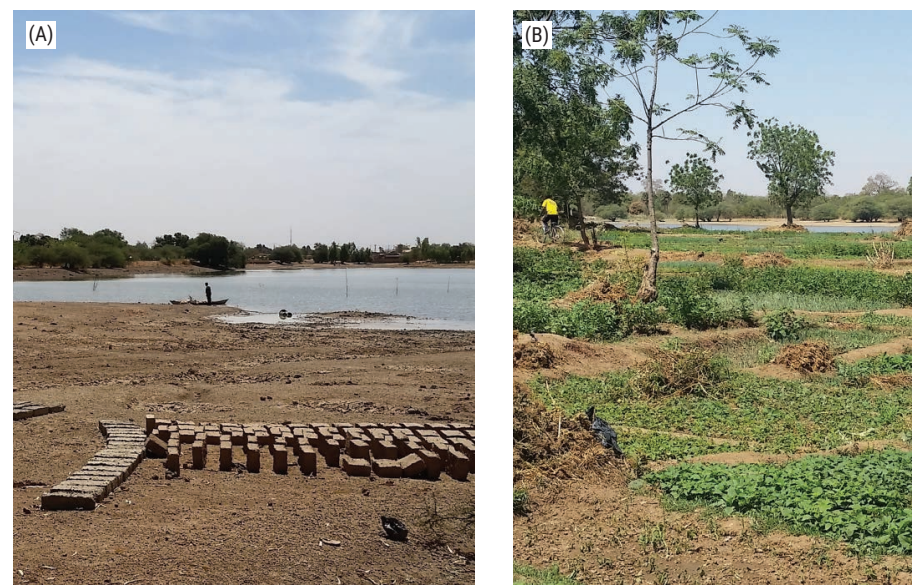

(C)

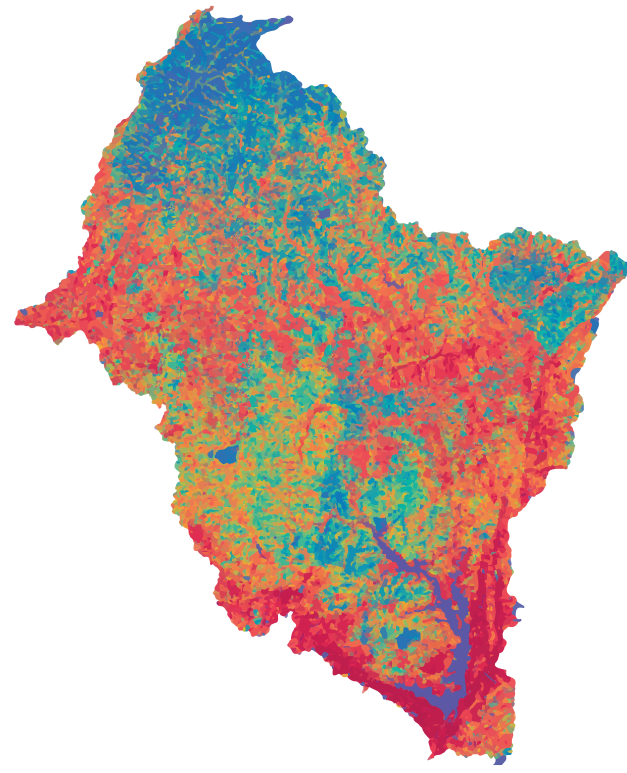

1.0

2200000.0

Figure 31.1 Making bricks in the Volta watershed (A), irrigated agriculture drawing from the Volta (B), and combining scores for five ecosystem services into a single conservation value metric (C) (Johnson et al. 2019)

green roofs and community gardens). However, the dense assemblage of people of different socio-economic and cultural backgrounds in cities makes it particularly important to consider ecosystem service beneficiaries, as well as the equity and justice implications of changes in ecosystem service provision (Keeler et al. 2019b). 


\section{Key readings}

Díaz S., U. Pascual, M. Stenseke, B. Martín-López, R.T. Watson, Z. Molnár, R. Hill et al. 2018. 'Assessing Nature's Contributions to People.' Science 359(6373): 270-272.

Millennium Ecosystem Assessment. 2005. Ecosystems and Human Well-being: Synthesis. Washington: Island Press.

Neugarten, R.A., P.F. Langhammer, E. Osipova, K.J. Bagstad, N. Bhagabati, S.H. Butchart, N. Dudley et al. 2018. Tools for Measuring, Modelling, and Valuing Ecosystem Services: Guidance for Key Biodiversity Areas, Natural World Heritage Sites, and Protected Areas. Gland: IUCN.

Reyers, B., R. Biggs, G.S. Cumming, T. Elmqvist, A.P. Hejnowicz, and S. Polasky. 2013. 'Getting the Measure of Ecosystem Services: A Social-Ecological Approach.' Frontiers in Ecology and the Environment 11(5): 268-273.

Rieb, J.T., R. Chaplin-Kramer, G.C. Daily, P.R. Armsworth, K. Böhning-Gaese, A. Bonn, G.S. Cumming et al. 2017. 'When, Where, and How Nature Matters for Ecosystem Services: Challenges for the Next Generation of Ecosystem Service Models.' BioScience 67: 820-833.

\section{References}

Abson, D.J., H. von Wehrden, S. Baumgärtner, J. Fischer, J. Hanspach, W. Härdtle, H. Heinrichs et al. 2014. 'Ecosystem Services as a Boundary Object for Sustainability.' Ecological Economics 103: 29-37.

Arkema, K., G. Guannel, G. Verutes, S.A. Wood, A. Guerry, M. Ruckelshaus, P. Kareiva et al. 2013. 'Coastal Habitats Shield People and Property from Sea-level Rise and Storms.' Nature Climate Change 3: 913.

Arkema, K., G. Verutes, S.A. Wood, C. Clarke-Samuels, S. Rosado, M. Canto, A. Rosenthal et al. 2015. 'Embedding Ecosystem Services in Coastal Planning Leads to Better Outcomes for People and Nature.' Proceedings of the National Academy of Sciences of the United States of America 112(24): 7390-7395.

Arndt, C., K. Strzepeck, F. Tarp, J. Thurlow, C. Fant IV, and L. Wright. 2011. 'Adapting to Climate Change: An Integrated Biophysical and Economic Assessment for Mozambique.' Sustainability Science 6(1): 7-20.

Bagstad, K., D.J. Semmens, S. Waage, and R. Winthrop. 2013. 'A Comparative Assessment of Decisionsupport Tools for Ecosystem Services Quantification and Valuation.' Ecosystem Services 5: 27-39.

Bratman, G., J.P. Hamilton, K.S. Hahn, G. Daily, and J.J. Gross. 2015. 'Nature Experience Reduces Rumination and Subgenual Prefrontal Cortex Activation.' Proceedings of the National Academy of Sciences 112(28): 8567-8572.

Chaigneau, T., S. Coulthard, K. Brown, T.M. Daw, and B. Schulte-Herbrüggen. 2018. 'Incorporating Basic Needs to Reconcile Poverty and Ecosystem Services.' Conservation Biology 33: 655-664.

Chan, K.M.A., P. Balvanera, K. Benessaiah, M. Chapman, S. Díaz, E. Gómez-Baggethun, R. Gould et al. 2016. 'Opinion: Why Protect Nature? Rethinking Values and the Environment.' Proceedings of the National Academy of Sciences 113(6): 1462-1465.

Chaplin-Kramer, R., R.P. Sharp, C. Weil, E.M. Bennett, U. Pascual, K. Arkema, K.A. Brauman et al. 2019. 'Global Modeling of Nature's Contributions to People.' Science 366(6462): 255-258.

Chaplin-Kramer, R., S. Sim, P. Hamel, B. Bryant, R. Noe, C. Mueller, G. Rigarlsford et al. 2017. 'Life Cycle Assessment Needs Predictive Spatial Modelling for Biodiversity and Ecosystem Services.' Nature Communications 8: 15065.

Curran, M.A. 1996. Environmental Life-cycle Assessment. New York: McGraw-Hill.

Daily, G. 1997. Nature's Services. Washington: Island Press.

Daw, T., K. Brown, S. Rosendo, and R. Pomeroy. 2011. 'Applying the Ecosystem Services Concept to Poverty Alleviation: The Need to Disaggregate Human Well-being.' Environmental Conservation 38(4): 370-379.

Daw, T.M., S. Coulthard, W.W.L. Cheung, K. Brown, C. Abunge, D. Galafassi, G.D. Peterson, T.R. McClanahan, J.O. Omukoto, and L. Munyi. 2015. 'Evaluating Taboo Trade-offs in Ecosystems Services and Human Well-being.' Proceedings of the National Academy of Sciences 112(22): 6949-6954.

De Groot, R., L. Brander, S. van der Ploeg, R. Costanza, F. Bernard, L. Braat, M. Christie et al. 2012. 'Global Estimates of the Value of Ecosystems and their Services in Monetary Units.' Ecosystem Services 1(1): 50-61. 
Díaz, S., S. Demissew, J. Carabias, C. Joly, M. Lonsdale, N. Ash, A. Larigauderie et al. 2015. 'The IPBES Conceptual Framework-Connecting Nature and People.' Current Opinion in Environmental Sustainability 14: 1-16.

Díaz, S., U. Pascual, M. Stenseke, B. Martín-López, R.T. Watson, Z. Molnár, R. Hill et al. 2018. 'Assessing Nature's Contributions to People.' Science 359(6373): 270-272.

Ehrlich, P.R., and A.H. Ehrlich. 1981. Extinction: The Causes and Consequences of the Disappearance of Species. New York: Random House.

Eigenbrod, F., P.R. Armsworth, B.J. Anderson, A. Heinemeyer, S. Gillings, D.B. Roy, C.D. Thomas, and K.J. Gaston. 2010. 'The Impact of Proxy-based Methods on Mapping the Distribution of Ecosystem Services.' Journal of Applied Ecology 47(2): 377-385.

Gomez-Baggethun, E., and M. Ruiz-Perez. 2011. 'Economic Valuation and the Commo-dification of Ecosystem Services.' Progress in Physical Geography 35(5): 613-628.

Guerry, A.D., S. Polasky, J. Lubchenco, R. Chaplin-Kramer, G.C. Daily, R. Griffin, M. Ruckelshaus et al. 2015. 'Natural Capital and Ecosystem Services Informing Decisions: From Promise to Practice.' Proceedings of the National Academy of Sciences 112(24): 7348-7355.

Hertel, T.W. 1997. Global Trade Analysis: Modeling and Applications. Cambridge: Cambridge University Press.

Johnson, J.A., U. Baldos, T. Hertel, J. Liu, C. Nootenboom, S. Polasky, and T. Roxburgh. 2020. 'Global Futures: Modelling the Global Economic Impacts of Environmental Change to Support Policy-making.' Technical Report, January 2020. London: WWF UK. www.wwf.org.uk/ globalfutures.

Johnson, J.A., S.K. Jones, S.L.R. Wood, R. Chaplin-Kramer, P.L. Hawthorne, M. Mulligan, D. Pennington, and F.A. DeClerck. 2019. 'Mapping Ecosystem Services to Human Well-being: A Toolkit to Support Integrated Landscape Management for the SDGs.' Ecological Applications 29(8): e01985. doi:10.1002/eap.1985.

Kareiva, P., H. Tallis, T.H. Ricketts, G.C. Daily, and S. Polasky. 2011. Natural Capital: Theory and Practice of Mapping Ecosystem Services. New York: Oxford University Press.

Keeler, B., B. Dalzell, J. Gourevitch, P. Hawthorne, K. Johnson, and R. Noe. 2019a. 'Putting People on the Map Improves the Prioritization of Ecosystem Services.' Frontiers in Ecology and the Environment 17(3): 151-156.

Keeler, B.L., P. Hamel, T. McPhearson, M. Hamann, M.L. Donahue, K.A.M. Prado, K.K. Arkema et al. 2019b. 'Social-Ecological and Technological Factors Moderate the Value of Urban Nature.' Nature Sustainability 2: 29-38.

Li, G., and C. Fang. 2014. 'Global Mapping and Estimation of Ecosystem Services Values and Gross Domestic Product: A Spatially Explicit Integration of National “Green GDP” Accounting.' Ecological Indicators 46: 293-314.

Malmborg, K., H. Sinare, E.E. Kautsky, I. Ouedraogo, and L.J. Gordon. 2018. 'Mapping Regional Livelihood Benefits from Local Ecosystem Services Assessments in Rural Sahel.' PLoS ONE 13(2): e0192019.

Mandle, L., J. Douglass, J.S. Lozano, R.P. Sharp, A.L. Vogl, D. Denu, T. Walschburger, and H. Tallis. 2016. 'OPAL: An Open-Source Software Tool for Integrating Biodiversity and Ecosystem Services into Impact Assessment and Mitigation Decisions.' Environmental Modelling \& Software 84: 121-133.

Mandle, L., H. Tallis, L. Sotomayor, and A. Vogl. 2015. 'Who Loses? Tracking Ecosystem Service Redistribution from Road Development and Mitigation in the Peruvian Amazon.' Frontiers in Ecology and the Environment 13(6): 309-315.

Mandle, L., S. Wolny, N. Bhagabati, H. Helsingen, P. Hamel, R. Bartlett, A. Dixon et al. 2017. 'Assessing Ecosystem Service Provision under Climate Change to Support Conservation and Development Planning in Myanmar.' PLoS ONE 12(9): e0184951.

Martínez-López, J., K.J. Bagstad, S. Balbi, A. Magrach, B. Voigt, I. Athanasiadis, M. Pascual, S. Willcock, and F. Villa. 2019. 'Towards Globally Customizable Ecosystem Service Models.' Science of the Total Environment 650: 2325-2336.

Martín-López, B., I. Iniesta-Arandia, M. García-Llorente, I. Palomo, I. Casado-Arzuaga, D.G. del Amo, E. Gómez-Baggethun et al. 2012. 'Uncovering Ecosystem Service Bundles through Social Preferences.' PLoS ONE 7(6): e38970.

Masterson, V.A., S. Vetter, T. Chaigneau, T.M. Daw, O. Selomane, M. Hamann, G.Y. Wong, V. Mellegård, M. Cocks, and M. Tengö. 2019. 'Revisiting the Relationships between Human Well-being and Ecosystems in Dynamic Social-Ecological Systems: Implications for Stewardship and Development.' Global Sustainability 2: e8. 
Metzger, M.J., D. Schröter, R. Leemans, and W. Cramer. 2008. 'A Spatially Explicit and Quantitative Vulnerability Assessment of Ecosystem Service Change in Europe.' Regional Environmental Change 8(3): 91-107.

Meyfroidt, P., E.F. Lambin, K. Erb, and T.W. Hertel. 2013. 'Globalization of Land Use: Distant Drivers of Land Change and Geographic Displacement of Land Use.' Current Opinion in Environmental Sustainability 5(5): 438-444.

Millennium Ecosystem Assessment. 2005. Ecosystems and Human Well-being: Synthesis. Washington: Island Press.

Moreno, J., I. Palomo, J. Escalera, B. Martín-López, and C. Montes. 2014. 'Incorporating Ecosystem Services into Ecosystem-based Management to Deal with Complexity: A Participative Mental Model Approach.' Landscape Ecology 29(8): 1407-1421.

Mulligan, M. 2012. 'WaterWorld: A Self-parameterising, Physically Based Model for Application in Data-poor but Problem-rich Environments Globally.' Hydrology Research 44(5): 748.

Mulligan, M., J.R. Rubiano, S. Burke, and A. van Soesbergen. 2013. 'Water Security in Amazonia.' Report for Global Canopy Programme and International Center for Tropical Agriculture as Part of the Amazonia Security Agenda Project.

Naidoo, R., A. Balmford, R. Costanza, B. Fisher, R.E. Green, B. Lehner, T.R. Malcolm, and T.H. Ricketts. 2008. 'Global Mapping of Ecosystem Services and Conservation Priorities.' Proceedings of the National Academy of Sciences 105(28): 9495-9500.

Nel, J.L., D.C. le Maitre, D.J. Roux, C. Colvin, J.S. Smith, L.B. Smith-Adao, A. Maherry, and N. Sitas. 2017. 'Strategic Water Source Areas for Urban Water Security: Making the Connection between Protecting Ecosystems and Benefiting from Their Services.' Ecosystem Services 28: 251-259.

Neugarten, R.A., P.F. Langhammer, E. Osipova, K.J. Bagstad, N. Bhagabati, S.H.M. Butchart, N. Dudley et al. 2018. Tools for Measuring, Modelling, and Valuing Ecosystem Services: Guidance for Key Biodiversity Areas, Natural World Heritage Sites, and Protected Areas. Gland: IUCN.

Nordhaus, W.D. 2017. 'Evolution of Assessments of the Economics of Global Warming: Changes in the DICE Model, 1992-2017.' NBER Working Paper No. 23319. Cambridge: National Bureau of Economic Research.

Olander, L.P., R.J. Johnston, H. Tallis, J. Kagan, L.A. Maguire, S. Polasky, D. Urban, J. Boyd, L. Wainger, and M. Palmer. 2018. 'Benefit Relevant Indicators: Ecosystem Services Measures that Link Ecological and Social Outcomes.' Ecological Indicators 85: 1262-1272.

Outeiro, L., E. Ojea, J.G. Rodrigues, A. Himes-Cornell, A. Belgrano, Y. Liu, E. Cabecinha et al. 2017. 'The Role of Non-natural Capital in the Co-production of Marine Ecosystem Services.' International Journal of Biodiversity Science, Ecosystem Services \& Management 13(3): 35-50.

Palomo, I., M.R. Felipe-Lucia, E.M. Bennett, B. Martín-López, and U. Pascual. 2016. 'Disentangling the Pathways and Effects of Ecosystem Service Co-Production.' Advances in Ecological Research 54: 245-283.

Pascual, U., I. Palomo, W.A. Adams, K.M.A. Chan, T.M. Daw, E. Garmendia, E. Gómez-Baggethun et al. 2017. 'Off-stage Ecosystem Service Burdens: A Blind Spot for Global Sustainability.' Environmental Research Letters 12(7): 75001.

Ramirez-Reyes, C., K.A. Brauman, R. Chaplin-Kramer, G.L. Galford, S.B. Adamo, C.B. Anderson, C. Anderson et al. 2019. 'Reimagining the Potential of Earth Observations for Ecosystem Service Assessments.' Science of the Total Environment 665: 1053-1063.

Reyers, B., R. Biggs, G.S. Cumming, T. Elmqvist, A.P. Hejnowicz, and S. Polasky. 2013. 'Getting the Measure of Ecosystem Services: A Social-Ecological Approach.' Frontiers in Ecology and the Environment 11(5): 268-273.

Rieb, J.T., R. Chaplin-Kramer, G.C. Daily, P.R. Armsworth, K. Böhning-Gaese, A. Bonn, G.S. Cumming et al. 2017. 'When, Where, and How Nature Matters for Ecosystem Services: Challenges for the Next Generation of Ecosystem Service Models.' BioScience 67(9): 820-833.

Schröter, M., T. Koellner, R. Alkemade, S. Arnhold, K.J. Bagstad, K. Erb, K. Frank et al. 2018. 'Interregional Flows of Ecosystem Services: Concepts, Typology and Four Cases.' Ecosystem Services 31: 231-241.

Sitch, S., B. Smith, I.C. Prentice, A. Arneth, A. Bondeau, W. Cramer, J.O. Kaplan et al. 2003. 'Evaluation of Ecosystem Dynamics, Plant Geography and Terrestrial Carbon Cy-cling in the LPJ Dynamic Global Vegetation Model.' Global Change Biology 9(2): 161-185.

Small, N., M. Munday, and I. Durance. 2017. 'The Challenge of Valuing Ecosystem Services that Have No Material Benefits.' Global Environmental Change 44: 57-67. 
Stanton, E.A., F. Ackerman, and S. Kartha. 2009. 'Inside the Integrated Assessment Models: Four Issues in Climate Economics.' Climate and Development 1(2): 166-184.

Van Vuuren, D.P., M. Kok, P.L. Lucas, A.G. Prins, R. Alkemade, M. van den Berg, L. Bouwman et al. 2015. 'Pathways to Achieve a Set of Ambitious Global Sustainability Objectives by 2050: Explorations Using the IMAGE Integrated Assessment Model.' Technological Forecasting and Social Change 98: 303-323.

Villa, F., K. Bagstad, B. Voigt, G. Johnson, R. Portela, M. Honzák, and D. Batker. 2014. 'A Methodology for Adaptable and Robust Ecosystem Services Assessment.’ PLoS ONE 9(3): e91001.

Westman, W. 1977. 'How Much Are Nature's Services Worth?’ Science 197(1969): 960-963.

Wood, S.A., A.D. Guerry, J.M. Silver, and M. Lacayo. 2013. 'Using Social Media to Quantify Nature-based Tourism and Recreation.' Scientific Reports 3: 1-7.

World Bank. 2018. 'Project Information Document (Appraisal Stage) - Volta River Basin Strategic Action Programme Implementation - P149969.' Washington: World Bank. 